\title{
The Effectiveness of Holistic Marketing and Word-of-Mouth Communication on Purchasing Decision at Pt Asuransi Central Asia Branch Office of Tiang Bendera West Jakarta
}

\author{
Lod Sulivyo $^{1 *}$; Riyan Siswoko ${ }^{1}$; Tegor $^{2}$ \\ ${ }^{1}$ STIE PPI Tangerang, Indonesia \\ ${ }^{2}$ Universitas Esa Unggul Jakarta, Indonesia \\ Email: romilod76@gmail.com
}

http://dx.doi.org/10.18415/ijmmu.v6i1.562

\begin{abstract}
Holistic marketing is a marketing concept that defines an overall corporate entity. Word-of-mouth communication is one way to spread rumors. Word-of-mouth communication is also the most ancient marketing strategy that is still widely implemented until now. The objectives of this research are: 1) to determine the effect of holistic marketing on purchasing decision; 2) to determine the effect of word-ofmouth communication on purchasing decision; 3) to determine the effect of holistic and word-of-mouth communication on purchasing decision. This research applied quantitative data collection method which was carried out through questionnaire distribution and literature studies. Based on the testing results of hypothesis 1, the holistic marketing variable (X1) and purchasing decision (Y) do not have a significant correlation because the sig. value $(\mathrm{p})=0.000<0.01$. Based on the testing results of hypothesis 2 , wordof-mouth communication (X2) and purchasing decisions (Y) have a significant correlation because the sig. value $(p)=0.000<0.01$. Based on the testing results of hypothesis 3 , holistic marketing (X1) and word-of-mouth communication (X2) variables on the purchasing decision variable (Y) are simultaneously and significantly related. The contribution of holistic marketing and word-of-mouth communication variables on purchasing decision is $86.1 \%$ and the remaining $13.9 \%$ is affected by other variables.
\end{abstract}

Keywords: Holistic Marketing; Word-of-Mouth Communication

\section{Introduction}

In current development, the role of marketing strategies is very important for the business world. Marketing is one of the main activities that must be carried out by the company-goods or services - in an effort to maintain the viability of its business. Marketing effectiveness is not only carried out through advertising and promotion mixes but also through all company departments or what so-called holistic marketing (Choi et al, 2015).

The holistic marketing concept understands that all aspects are very important in marketing which includes the products, employees, competitors, and even the surrounding environment. Therefore, a 
broader and more integrated perspective is needed in seeing this point. According to Kotler and Keller (2009), holistic marketing is a concept in marketing that defines a company entity as a whole and not just a corporation. Therefore, currently, the holistic marketing concept is widely used by companies in order to maintain the going-concern level in the business world (Tsai, 2005). The definition of the company as a whole in holistic marketing is to see the company as a whole that is integrated with various other elements. These elements include customers (consumers), stakeholders, and suppliers. Companies must regard consumers as the most important part in the development of the company because consumers have a large share in the success of the company and they can create word-of-mouth communication (Kim et al, 2009).

Word of mouth in Indonesian is also called stories spreading from mouth to mouth. Word-ofmouth communication refers to oral communication with friends, family, and colleagues about various products. Word-of-mouth communication is one way to spread rumors. Word-of-mouth communication is also the most ancient marketing strategy that is still widely implemented until now. Almost all businesses rely on their success with word-of-mouth communication. By using word-of-mouth communication, a consumer who feels satisfied will tell or recommend a product to his/ her friends so that they use or buy the product (Wangenheim \& Bayón, 2007).

This strategy is very appropriate for promotional efforts because it can tell and preach a positive thing. All stories also come from the quality of the product or service provided by a company/ industry; whether or not all expectations of consumers who use these products and services are met. If consumers are loyal, word-of-mouth communication will work well. Oral communication is one of the ways used by marketers in carrying out promotional activities; in addition to other forms of promotion which include advertising, publications and so forth. In contrast to the form of marketing communication in general, the strategy of word-of-mouth communication has a greater chance of achieving the target (Hennig-Thurau et al, 2004). It is because word-of-mouth communication is translated and packaged in symbolic form before an information is conveyed through the communication channel to the recipient of the message. Thus, the information conveyed can be directly received by the target who in general are people who need that information.

Some experts in marketing communication try to define word-of-mouth communication from various perspectives. According to Hasan (2010) word-of-mouth communication is the act of consumers in providing information to other consumers (between individuals) on a non-commercial basis about brands, products and services. Rangkuti (2009) defined word-of-mouth communication as a marketing effort that triggers customers to discuss, promote, recommend, and sell a product, service, and/ or brand to other customers. Hasan (2010) suggested the reasons for making word-of-mouth communication succeed in becoming a strong source of information in influencing purchasing decision. Purchasing decision is largely determined by customer satisfaction that has used the products and the concerns from the entire department of the company.

According to Kotler and Armstrong (2012), consumer's purchasing decision is an act of buying the most preferred brand from various alternatives; however, two factors can be between purchase intention and purchasing decision. The first factor is the attitude of other people and the second factor is situational factor. The specific purchasing decision process according to Kotler and Armstrong (2012) consists of the following sequence of events: introduction of problem needs, information seeking, evaluation of alternatives, purchasing decision and post-purchase behavior. 


\section{Methododology \\ 2.1 Research Design}

This research applied descriptive research design using a quantitative approach method. Quantitative research itself is a study that collects data in the form of numbers or qualitative data that are converted to numbers. These data are obtained from the results of the questionnaire answers. It is similar to what Sugiyono (2012) stated about this quantitative research method, in which "it is a research method based on positivist philosophy and is used to examine certain populations or samples where data collection uses research instruments and quantitative/ statistical data analysis with the purpose to test the predetermined hypothesis". In addition, the descriptive research itself according to Sugiyono (2012) is research conducted to determine the value of independent variables (one or more variables) without making comparisons or correlating them with other variables. Based on the approach used in this research, many quantitative research methods use quantitative data.

\subsection{Data Sources and Types}

The data types used in this research are as follows:

1. Primary Data

Sugiyono (2012) argues that "primary data source is a data source that directly provides data to data collectors".

2. Secondary Data

Secondary data is a data source that does not provide information directly to data collectors. According to Sugiyono (2012), this secondary data source can be the result of further processing of primary data that is presented in other forms or comes from other people.

\subsection{Data Collection Method}

Sugiyono (2013) stated that data collection technique is the most strategic step in a research since the main objective of a research is to obtain data. In this case, the data research method used in this research is a quantitative data collection method which was conducted through questionnaire distribution and literature studies.

\subsection{Population and Samples}

The population of this research is considered to include consumers or customers of PT Asuransi Central Asia. The samples used in this research are 100 respondents that theoretically are sufficiently produced accurate data according to Fanklen and Walen in Sugiyono. Research sampling that will be analyzed in this research is obtained randomly (random sampling technique). 


\subsection{Research Variables}

In this research, there are two kinds of variables; i.e. dependent variable or variable that depend on other variables and independent variables. The research variables are as follows:

1. Independent Variables

a) Holistic Marketing (X1)

b) Word of Mouth Communication (X2)

2. Dependent Variable

a) Purchasing Decision

\subsection{Hypothesis Testing}

a) Partial Linear Regression Test

Partial regression is based on functional or causal correlation of one independent variable with one dependent variable.

\section{b) $t$-Test}

The t-statistic test basically shows to what extent the effect of one independent variable individually explains the variation of the dependent variable.

\section{c) Multiple Linear Regression Test}

To test the hypothesis about the strength of the independent variables on the dependent variable, this research applies multiple regression analysis with the equation of Ordinary Least Squares (OLS) (Imam Ghozali, 2011: 96).

\section{d) Simultaneous Test (F-Test)}

The F test aims to determine the simultaneous effect of independent variables on the dependent variable.

\section{e) Partial and Multiple Correlation Coefficient}

1) Partial Correlation Coefficient

According to Sugiyono (2013) partial (simple) correlation is used to analyze research that aims to determine the effect or determine the correlation between independent and dependent variables in which one of the independent variables is permanent/ controlled. Therefore, partial correlation is a number that shows the direction and strength of the correlation between two or more variables; after one variable that is expected to affect the correlation of the variables is permanent/ controlled. 


\section{2) Multiple Correlation Coefficient}

According to Sugiyono (2013), multiple correlation is a number that shows the direction and strength of the correlation between two independent variables or more with the dependent variable simultaneously.

\section{f) Determination Coefficient Test (R2)}

The determination coefficient $\mathrm{R}^{2}$ is used to find out what percentage of dependent variation can be explained by variations in independent variables. This $R^{2}$ values range between 0 and 1 . If the $R^{2}$ value approaches 0 , it means that there is very little variation in the dependent variable that can be explained by the independent variable. If the $\mathrm{R}^{2}$ value approaches 1 , it means that there is a greater variation in the dependent variable that can be explained by the independent variable. If the calculation of $\mathrm{R}^{2}$ value produces 0 then it shows that the dependent variable cannot be explained by the independent variable.

\section{Result and Discussion}

\subsection{Hypothesis 1}

\section{Results of Correlation Testing}

Ho: There is no effect of holistic marketing on purchasing decision at PT Asuransi Central Asia Branch Office of Tiang Bendera West Jakarta.

Ha: There is an effect of holistic marketing on purchasing decision at PT Asuransi Central Asia Branch Office of Tiang Bendera West Jakarta.

Table 1 Regression Descriptive Statistics

\begin{tabular}{lccc}
\hline & Mean & Std. Deviation & $\mathrm{N}$ \\
\hline Purchasing Decision & 19.35 & 3.118 & 100 \\
Holistic Marketing & 30.99 & 5.044 & 100 \\
\hline
\end{tabular}

Source: SPSS 21

This section shows the description of the two regressed variables; i.e. Purchasing Decision (Y) and Holistic Marketing (X1). The contents of the description are: mean of $\mathrm{Y}=19.35$ and $\mathrm{X} 1=30.99$. The standard deviation of $\mathrm{Y}=3.118$ and $\mathrm{X} 1=5.044$ and $\mathrm{N}$ (number of subjects $=100$ ).

Table 2 Correlation

\begin{tabular}{llcc}
\hline & Purchasing & $\begin{array}{c}\text { Holistic } \\
\text { Decision }\end{array}$ & $\begin{array}{c}\text { Marketing } \\
\text { Pearson Correlation }\end{array}$ \\
& Purchasing Decision & 1.000 & .927 \\
Holistic Marketing & .927 & 1.000 \\
Sig. (1-tailed) & Purchasing Decision &. & .000 \\
\multirow{2}{*}{$\mathrm{N}$} & Holistic Marketing & .000 &. \\
& Purchasing Decision & 100 & 100 \\
\hline
\end{tabular}


This section presents the results of regression calculations for the variables that had been analyzed. Basically, analysis by using regression must firstly check the correlation. The correlation between $\mathrm{X} 1$ and $\mathrm{Y}$ is 0.927 with a significance of 0.000 .

Table 3 Model Summary ${ }^{\mathrm{b}}$

\begin{tabular}{lcccc}
\hline Model & $\mathrm{R}$ & $\mathrm{R}$ Square & $\begin{array}{c}\text { Adjusted R } \\
\text { Square }\end{array}$ & $\begin{array}{l}\text { Std. Error of the } \\
\text { Estimate }\end{array}$ \\
\hline 1 & $.927^{\mathrm{a}}$ & .860 & .859 & 1.172 \\
\hline
\end{tabular}

a. Predictors: (Constant), Holistic Marketing

b. Dependent Variable: Purchasing Decision

This section presents:

- $\mathrm{R}$ value $=0.927$

- Determination coefficient $R^{2}(R$ Square $)=0.860$

The value is obtained from squaring the correlation coefficient $(0.927 \times 0.927)$. It shows that the percentage index of determination contributes to the effect of $\mathrm{X} 1$ on $\mathrm{Y} . \mathrm{R}^{2}=0.860$ means that the contribution of $\mathrm{X} 1$ to $\mathrm{Y}$ is $86 \%$, while the remaining $14 \%$ is affected by other factors $(100 \%-86 \%)$.

$\mathrm{R}$ ranges from 0 to 1 ; with the note that smaller $\mathrm{R}$ value shows the weaker correlation between variables $\mathrm{X} 1$ and $\mathrm{Y}$.

Table 4 Coefficients ${ }^{\mathrm{a}}$

\begin{tabular}{|c|c|c|c|c|c|c|}
\hline \multirow[t]{2}{*}{ Model } & & \multicolumn{2}{|c|}{ Unstandardized Coefficients } & Standardized & \multirow[t]{2}{*}{$\mathrm{T}$} & \multirow[t]{2}{*}{ Sig. } \\
\hline & & $\mathrm{B}$ & Std. Error & Beta & & \\
\hline \multirow{2}{*}{1} & (Constant) & 1.581 & .733 & & 2.157 & .033 \\
\hline & Holistic Marketing & .573 & .023 & .927 & 24.557 & .000 \\
\hline
\end{tabular}

a. Dependent Variable: Purchasing Decision

Source: SPSS 21

$\mathrm{Y}=1.581+0.573 \mathrm{X} 1$

Description:

$\mathrm{Y}=$ Purchasing Decision and X1 = Holistic Marketing

The value of 1.581 is the constant (B) value which indicates that if there is no increase in the Purchasing Decision value, Holistic Marketing value will reach 1.581. Meanwhile, the value of 0.573 for $\mathrm{X} 1$ is a regression coefficient. The value of 0.972 for the standardized coefficient (Beta) shows the level of correlation between Purchasing Decision and Holistic Marketing.

The t-value is used to test whether or not Holistic Marketing and Purchasing Decision really have a significant effect.

\section{Conclusion}

$\mathrm{t}=2.557$, sig. $(\mathrm{p})=0.000$, and $\mathrm{p}=0.000<0.01$

Ho: rejected and Ha: accepted

So, there is no effect of $\mathrm{X} 1$ on Y variable. 
R square $=86 \%$ is a Holistic Marketing contribution to Purchasing Decision, while the remaining $14 \%$ is affected by other factors.

Table 5 Residuals Statistics ${ }^{\mathrm{a}}$

\begin{tabular}{lccccc}
\hline & Minimum & Maximum & Mean & Std. Deviation & $\mathrm{N}$ \\
\hline Predicted Value & 11.33 & 23.94 & 19.35 & 2.892 & 100 \\
Std. Predicted Value & -2.773 & 1.588 & .000 & 1.000 & 100 \\
Standard Error of Predicted & .117 & .347 & .160 & .044 & 100 \\
Value & & & & & \\
Adjusted Predicted Value & 11.46 & 23.94 & 19.35 & 2.890 & 100 \\
Residual & -4.796 & 3.085 & .000 & 1.166 & 100 \\
Std. Residual & -4.093 & 2.632 & .000 & .995 & 100 \\
Stud. Residual & -4.143 & 2.665 & -.001 & 1.005 & 100 \\
Deleted Residual & -4.916 & 3.161 & -.002 & 1.191 & 100 \\
Stud. Deleted Residual & -4.539 & 2.753 & -.004 & 1.031 & 100 \\
Mahal. Distance & .000 & 7.692 & .990 & 1.276 & 100 \\
Cook's Distance & .000 & .214 & .011 & .025 & 100 \\
Centered Leverage Value & .000 & .078 & .010 & .013 & 100 \\
\hline
\end{tabular}

a. Dependent Variable: Purchasing Decision

Table of residual statistics provides an overview of the summary of the minimum, maximum, mean, of the standard deviation of the predicted value of the number of subjects.

\subsection{Hypothesis 2}

Ho: There is no effect of word-of-mouth communication on purchasing decision at PT Asuransi Central Asia Branch Office of Tiang Bendera West Jakarta.

Ha: There is an effect of word-of-mouth communication on purchasing decision at PT Asuransi Central Asia Branch Office of Tiang Bendera West Jakarta.

Table 6 Descriptive Statistics

\begin{tabular}{lccc}
\hline & Mean & Std. Deviation & $\mathrm{N}$ \\
\hline Purchasing Decision & 19.35 & 3.118 & 100 \\
WoM Communication & 19.29 & 3.491 & 100 \\
\hline
\end{tabular}

This section shows the description of the two regressed variables; i.e. Purchasing Decision (Y) and Word-of-Mouth Communication (X2). The contents of the description are: mean of Y $=19.35$ and $\mathrm{X} 2=19.29$.

The standard deviation of $\mathrm{Y}=3.118$ and $\mathrm{X} 2=3.491$ and $\mathrm{N}$ (number of subjects $=100$ ). 
Table 7 Correlations

\begin{tabular}{llcc}
\hline & & $\begin{array}{c}\text { Purchasing } \\
\text { Decision }\end{array}$ & $\begin{array}{c}\text { WoM } \\
\text { Communication }\end{array}$ \\
\hline \multirow{2}{*}{ Pearson Correlation } & Purchasing Decision & 1.000 & .717 \\
Sig. (1-tailed) & WoM Communication & .717 & 1.000 \\
& Purchasing Decision &. & .000 \\
$\mathrm{~N}$ & WoM Communication & .000 &. \\
& Purchasing Decision & 100 & 100 \\
& WoM Communication & 100 & 100 \\
\hline
\end{tabular}

This section presents the results of regression calculations for the variables that had been analyzed. Basically, analysis by using regression must firstly check the correlation. The correlation between $\mathrm{X} 2$ and $\mathrm{Y}$ is 0.717 with a significance of 0.000 .

Table 8 Model Summary ${ }^{\mathrm{b}}$

\begin{tabular}{lccll}
\hline Model & $\mathrm{R}$ & $\mathrm{R}$ Square & $\begin{array}{l}\text { Adjusted } \\
\text { Square }\end{array}$ & $\begin{array}{c}\text { RStd. Error of the } \\
\text { Estimate }\end{array}$ \\
\hline 1 & $.717^{\mathrm{a}}$ & .514 & .509 & 2.185 \\
\hline
\end{tabular}

a. Predictors: (Constant), WoM Communication

b. Dependent Variable: Purchasing Decision

Source: SPSS 21

This section presents:

- $\mathrm{R}$ value $=0.717$

- Determination coefficient $R^{2}(R$ Square $)=0.514$

The value is obtained from squaring the correlation coefficient $(0.717 \times 0.717)$. It shows that the percentage index of determination contributes to the effect of $\mathrm{X} 2$ on $\mathrm{Y} . \mathrm{R}^{2}=0.514$ means that the contribution of $\mathrm{X} 2$ to $\mathrm{Y}$ is $51.4 \%$, while the remaining $48.6 \%$ is affected by other factors $(100 \%-51.4 \%)$. $\mathrm{R}$ ranges from 0 to 1 ; with the note that smaller $\mathrm{R}$ value shows the weaker correlation between variables $\mathrm{X} 2$ and $\mathrm{Y}$.

Table 9 Coefficients ${ }^{\mathrm{a}}$

\begin{tabular}{|c|c|c|c|c|c|c|}
\hline \multirow[t]{2}{*}{ Model } & & \multicolumn{2}{|c|}{ Unstandardized Coefficients } & \multirow{2}{*}{$\begin{array}{c}\begin{array}{l}\text { Standardized } \\
\text { Coefficients }\end{array} \\
\text { Beta }\end{array}$} & \multirow{2}{*}{$\mathrm{T}$} & \multirow{2}{*}{ Sig. } \\
\hline & & $\mathrm{B}$ & Std. Error & & & \\
\hline & (Constant) & 6.994 & 1.233 & & 5.674 & .000 \\
\hline 1 & $\begin{array}{l}\text { WoM } \\
\text { Communicat } \\
\text { ion }\end{array}$ & .641 & .063 & .717 & 10.184 & .000 \\
\hline
\end{tabular}

a. Dependent Variable: Purchasing Decision

Source: SPSS 21

$\mathrm{Y}=6.994+0.641 \mathrm{X} 2$

Description:

$\mathrm{Y}=$ Purchasing Decision and X2 $=$ Word-of-Mouth Communication 
The value of 6.994 is the constant (B) value which indicates that if there is no increase in the Purchasing Decision value, Word-of-Mouth Communication value will reach 6.994. Meanwhile, the value of 0.641 for $\mathrm{X} 2$ is a regression coefficient. The value of 0.717 for the standardized coefficient (Beta) shows the level of correlation between Purchasing Decision and Word-of-Mouth Communication.

The t-value is used to test whether or not Word-of-Mouth Communication and Purchasing Decision really have a significant effect.

\section{Conclusion}

$\mathrm{t}=10.184$, sig. $(\mathrm{p})=0.000$, and $\mathrm{p}=0.000<0.01$

Ho: rejected and Ha: accepted

So, there is an effect of $\mathrm{X} 2$ on $\mathrm{Y}$ variable.

$\mathrm{R}$ square $=51.4 \%$ is a Word-of-Mouth Communication contribution to Purchasing Decision, while the remaining $48.6 \%$ is affected by other factors.

Table 10 Residuals Statistics ${ }^{\mathrm{a}}$

\begin{tabular}{lccccc}
\hline & Minimum & Maximum & Mean & Std. Deviation & $\mathrm{N}$ \\
\hline Predicted Value & 12.12 & 23.01 & 19.35 & 2.236 & 100 \\
Std. Predicted Value & -3.234 & 1.636 & .000 & 1.000 & 100 \\
Standard Error of Predicted & .219 & .743 & .296 & .089 & 100 \\
Value & & & & & \\
Adjusted Predicted Value & 12.00 & 23.05 & 19.35 & 2.234 & 100 \\
Residual & -5.164 & 6.679 & .000 & 2.174 & 100 \\
Std. Residual & -2.364 & 3.057 & .000 & .995 & 100 \\
Stud. Residual & -2.376 & 3.125 & .000 & 1.006 & 100 \\
Deleted Residual & -5.217 & 6.977 & -.001 & 2.220 & 100 \\
Stud. Deleted Residual & -2.435 & 3.276 & .000 & 1.019 & 100 \\
Mahal. Distance & .007 & 10.458 & .990 & 1.474 & 100 \\
Cook's Distance & .000 & .218 & .011 & .026 & 100 \\
Centered Leverage Value & .000 & .106 & .010 & .015 & 100 \\
\hline
\end{tabular}

a. Dependent Variable: Purchasing Decision

Source: SPSS 21

The Table of residual statistics provides an overview of the summary of the minimum, maximum, mean, of the standard deviation of the predicted value of the number of subjects.

\subsection{Hypothesis 3}

Ho: There is no effect of holistic marketing and word-of-mouth communication on purchasing decision at PT Asuransi Central Asia Branch Office of Tiang Bendera West Jakarta.

Ha: There is an effect of holistic marketing and word-of-mouth communication on purchasing decision at PT Asuransi Central Asia Branch Office of Tiang Bendera West Jakarta. 
Table 11 Descriptive Statistics

\begin{tabular}{lccc}
\hline & Mean & Std. Deviation & $\mathrm{N}$ \\
\hline Purchasing Decision & 19.35 & 3.118 & 100 \\
Holistic Marketing & 30.99 & 5.044 & 100 \\
WoM Communication & 19.29 & 3.491 & 100 \\
\hline
\end{tabular}

This section shows the description of the three regressed variables; i.e. Purchasing Decision (Y), Holistic Marketing (X1), and Word-of-Mouth Communication (X2). The contents of the description are: mean of $\mathrm{Y}=19.35, \mathrm{X} 1=30.99$, and $\mathrm{X} 2=19.29$.

The standard deviation of $\mathrm{Y}=3.118, \mathrm{X} 1=5.044$, and $\mathrm{X} 2=3.491$ and $\mathrm{N}$ (number of subjects $=100$ ).

Table 12 Correlations

\begin{tabular}{llccc}
\hline & & $\begin{array}{c}\text { Purchasing } \\
\text { Decision }\end{array}$ & $\begin{array}{c}\text { Holistic } \\
\text { Marketing }\end{array}$ & $\begin{array}{l}\text { WoM } \\
\text { Communic } \\
\text { ation }\end{array}$ \\
\hline Pearson Correlation & Purchasing Decision & 1.000 & .927 & .717 \\
& Holistic Marketing & .927 & 1.000 & .786 \\
& WoM Communication & .717 & .786 & 1.000 \\
Sig. (1-tailed) & Purchasing Decision &. & .000 & .000 \\
& Holistic Marketing & .000 &. & .000 \\
$\mathrm{~N}$ & WoM Communication & .000 & .000 &. \\
& Purchasing Decision & 100 & 100 & 100 \\
& Holistic Marketing & 100 & 100 & 100 \\
& WoM Communication & 100 & 100 & 100 \\
\hline
\end{tabular}

This section presents the results of regression calculations for the variables that had been analyzed. Basically, analysis by using regression must firstly check the correlation. The correlation between $\mathrm{X} 1$ and $\mathrm{Y}$ is 0.927 with a significance of 0.000 . In addition, correlation between $\mathrm{X} 2$ and $\mathrm{Y}$ is 0.717 .

Table 13 Model Summary ${ }^{\mathrm{b}}$

\begin{tabular}{ccccc}
\hline Model & $\mathrm{R}$ & R Square & $\begin{array}{l}\text { Adjusted } \\
\text { Square }\end{array}$ & $\begin{array}{c}\text { RStd. Error of the } \\
\text { Estimate }\end{array}$ \\
\hline 1 & $.928^{\mathrm{a}}$ & .861 & .858 & 1.176 \\
\hline
\end{tabular}

a. Predictors: (Constant), WoM Communication, Holistic

Marketing

b. Dependent Variable: Purchasing Decision

Source: SPSS 21

This section presents:

- $\mathrm{R}$ value $=0.928$

- Determination coefficient $R^{2}(R$ Square $)=0.861$

The value is obtained from squaring the correlation coefficient $(0.928 \times 0.928)$. It shows that the percentage index of determination contributes to the effect of X1 and X2 on $\mathrm{Y} . \mathrm{R}^{2}=0.861$ means that the 
contribution of $\mathrm{X} 1$ and $\mathrm{X} 2$ to $\mathrm{Y}$ is $86.1 \%$, while the remaining $13.9 \%$ is affected by other factors (100\% $86.1 \%)$.

$\mathrm{R}$ ranges from 0 to 1 ; with the note that smaller $\mathrm{R}$ value shows the weaker correlation between variables $\mathrm{X} 1$ and $\mathrm{X} 2$ to $\mathrm{Y}$.

Table 14 ANOVA $^{\mathrm{a}}$

\begin{tabular}{llccccc}
\hline Model & & Sum of Squares & Df & Mean Square & F & Sig. \\
\hline \multirow{3}{*}{1} & Regression & 828.526 & 2 & 414.263 & 299.377 & $.000^{\mathrm{b}}$ \\
& Residual & 134.224 & 97 & 1.384 & & \\
& Total & 962.750 & 99 & & & \\
\hline
\end{tabular}

a. Dependent Variable: Purchasing Decision

b. Predictors: (Constant), WoM Communication, Holistic Marketing

Source: SPSS 21

F-value $=299.377$ with a significance level $(p)=0.000$ indicates that there is an effect of X1 and X2 variables on Y variable.

General Conclusion:

$\mathrm{F}=299.377$ and $\mathrm{p}=0.000<0.1$

Ho: rejected and Ha: accepted

Thus, there is a significant effect of Holistic Marketing and Word of Mouth Communication on Purchasing Decision.

Table 15 Residuals Statistics ${ }^{\mathrm{a}}$

\begin{tabular}{lccccc}
\hline & Minimum & Maximum & Mean & Std. Deviation & $\mathrm{N}$ \\
\hline Predicted Value & 11.38 & 24.07 & 19.35 & 2.893 & 100 \\
Std. Predicted Value & -2.757 & 1.632 & .000 & 1.000 & 100 \\
Standard Error of Predicted & .119 & .455 & .193 & .065 & 100 \\
Value & & & & & \\
Adjusted Predicted Value & 11.52 & 24.08 & 19.35 & 2.891 & 100 \\
Residual & -4.784 & 3.084 & .000 & 1.164 & 100 \\
Std. Residual & -4.067 & 2.621 & .000 & .990 & 100 \\
Stud. Residual & -4.118 & 2.654 & .000 & 1.004 & 100 \\
Deleted Residual & -4.905 & 3.160 & .000 & 1.198 & 100 \\
Stud. Deleted Residual & -4.510 & 2.742 & -.003 & 1.029 & 100 \\
Mahal. Distance & .019 & 13.847 & 1.980 & 2.345 & 100 \\
Cook's Distance & .000 & .144 & .010 & .019 & 100 \\
Centered Leverage Value & .000 & .140 & .020 & .024 & 100 \\
\hline
\end{tabular}

a. Dependent Variable: Purchasing Decision 
The Table of residual statistics provides an overview of the summary of the minimum, maximum, mean, of the standard deviation of the predicted value of the number of subjects.

\section{Discussion}

Based on the research findings, after data analyzing using the statistical method was carried out, those research findings can be described as follows:

Based on the test result of hypothesis 1, holistic marketing (X1) and purchasing decision (Y) variables have a significant correlation because the sig. value $(p)=0.000<0.01$. Therefore, Ho is rejected and $\mathrm{Ha}$ is accepted. Based on the test result of hypothesis 2, word-of-mouth communication (X2) and purchasing decision $(\mathrm{Y})$ have a significant correlation because the sig. value $(\mathrm{p})=0.000<0.01$. Therefore, Ho is rejected and $\mathrm{Ha}$ is accepted. Based on the test result of hypothesis 3, holistic marketing (X1) and word-of-mouth communication (X2) variables have a significant and simultaneous correlation on purchasing decision (Y) variable. The contribution of holistic marketing and word-of-mouth communication variables on purchasing decision variable is $86.1 \%$, and the remaining $13.9 \%$ is affected by other variables.

\section{Conclusion}

Based on the analysis results that have been carried out by the researchers, the following conclusions can be drawn:

Based on the results of hypothesis testing between holistic marketing (X1) and purchasing decision (Y) variables, Ho is rejected and Ha is accepted. It is concluded that there is an effect of holistic marketing on purchasing decision at PT Asuransi Central Asia Branch Office of Tiang Bendera West Jakarta. Based on the results of hypothesis testing between word-of-mouth communication (X2) and purchasing decision $(\mathrm{Y})$ variables, Ho is rejected and $\mathrm{Ha}$ is accepted. It is concluded that there is an effect of word-of-mouth communication on purchasing decision at PT Asuransi Central Asia Branch Office of Tiang Bendera West Jakarta. Based on the results of hypothesis testing between holistic marketing (X1) and word-of-mouth communication (X2) on purchasing decision (Y) variables, Ho is rejected and Ha is accepted. It is concluded that holistic marketing (X1) and word-of-mouth communication (X2) simultaneously have an effect on purchasing decision (Y). Contribution of holistic marketing and wordof-mouth communication variables simultaneously on purchasing decision is $86.1 \%$ and the rest is determined by other variables.

\section{Suggestion}

Based on the description above, the researchers give the following suggestions:

All company divisions need to get an understanding of products and product quality so that they can help and provide information to customers. It is recommended to provide good service to customers so that they talk positive things about the company to other prospective customers. Future research should use other variables that can complement the independent variables of holistic marketing (X1) and wordof-mouth communication (X2) on purchasing decision (Y). 


\section{References}

Choi, H., Ko, E., Kim, E. Y., \& Mattila, P. (2015). The Role of Fashion Brand Authenticity in Product Management: A Holistic Marketing Approach. Journal of Product Innovation Management, 32(2): 233242.

Hasan, A. (2010). Marketing Dari Mulut Ke Mulut (Word of Mouth Marketing, Yogyakarta: Media Press.

Hennig-Thurau, T., Gwinner, K. P., Walsh, G., \& Gremler, D. D. (2004). Electronic Word-of-Mouth via Consumer-Opinion Platforms: What Motivates Consumers to Articulate Themselves on the Internet?. Journal of interactive marketing, 18(1): 38-52.

Kim, W. G., Ng, C. Y. N., \& Kim, Y. S. (2009). Influence of Institutional DINESERV on Customer Satisfaction, Return Intention, and Word-of-Mouth. International Journal of Hospitality Management, 28(1): 10-17.

Kotler \& Keller. (2009). Manajemen Pemasaran. Jilid I. Edisi ke 13. Jakarta: Erlangga.

Kotler, P., \& Armstrong, G. (2012). Defining Marketing and the Marketing Process. Principles of Marketing, 14th Edition, New Jersey: Pearson Prentice Hall.

Rangkuti, F. (2009). Strategi Promosi yang Kreatif dan Analisis Kasus Integrated Marketing Communication. Jakarta: GramediaPustakaUtama.

Sugiyono. (2012). Memahami Penelitian Kualitatif. Bandung: Alfabeta.

Sugiyono. (2013). Statitika Untuk Penelitian. Bandung: Alfabeta.

Sugiyono. (2013). Metode Penelitian Pendidikan (Pendekatan Kuantitatif, Kualitatif, dan R \& D). Bandung: Alfabeta.

Tsai, S. P. (2005). Integrated Marketing as Management of Holistic Consumer Experience. Business Horizons, 48(5): 431-441.

Wangenheim, F. V., \& Bayón, T. (2007). The Chain from Customer Satisfaction via Word-of-Mouth Referrals to New Customer Acquisition. Journal of the Academy of Marketing Science, 35(2): 233-249.

\section{Copyrights}

Copyright for this article is retained by the author(s), with first publication rights granted to the journal.

This is an open-access article distributed under the terms and conditions of the Creative Commons Attribution license (http://creativecommons.org/licenses/by/4.0/). 